\title{
EFFECT OF WORKLOAD, COMPENSATION AND EMPLOYEE COMMITMENT TO THE EMPLOYEES PERFORMANCE OF PUBLIC WORKS AND SPATIAL ARRANGEMENTS OFFICE OF KARIMUN DISTRICT
}

\author{
Mohamad Almansa Fitra ${ }^{1}$, Indrayani ${ }^{2}$, Andykhatria ${ }^{3}$, Syahril $^{4}$, \\ Hasudungan Hutasoit ${ }^{5}$, I Wayan Catra Yasa ${ }^{6}$ \\ 1,2,3,4,5,6 Department of Management Master Program Batam University, Indonesia \\ Correspondence Address : Jl. Abdulyatama No 5, Batam, Kepulauan Riau. \\ E-mail: ${ }^{1)}$ fitra.almansa@ gmail.com
}

\begin{abstract}
This study aims to determine and describe how the influence of professionalism in managing village assets, optimizing the use of village assets and empowering the community so that it contributes to increasing village original income. The type of data used in this research is quantitative data. The data source in this research is secondary data. The object of this research is Kuala Sempang Village, Seri Kuala Lobam District, Bintan Regency. The results showed that the professionalism of village asset management had no significant effect on village original income, the optimization of the village assets utilization had a significant positive effect on village original income and community empowerment had no significant effect on village original income. So, in this study from the three variables only one variable has a significant positive effect on the village's original income. This study aims to analyze the influence of workload, work experience and work motivation on employee performance. The type of research used in this study is associative research. The method that can be used in this study is to use structural equation modeling (SEM) analysis based on variance, namely Partial Least Square (PLS). SEM with variance-based PLS so that it is able to handle two conditions, namely conditions with unspecified factors and conditions where the solution is unacceptable. This study uses computer smart program PLS 3.3.3. The population of this study is Civil Servants in the Public Works and Spatial Planning Office of Karimun Regency which amounts to 66 employees. The research data was collected by questionnaire instrument. The test results hypothesized the direct influence of workload with employee performance showed insignificant negative results (inner weight $=-0.302, p=0.149$ ) so it can be concluded that the results of the study rejected hypothesis 1 because there is an insignificant influence between workloads on employee performance. The test results of the hypothesis of direct influence of work experience showed insignificant positive results (inner weight $=0.062, p=0.717$ ) so it can be concluded that the results of the study rejected hypothesis 2 because there is an insignificant influence between work experience and employee performance. The test results hypothesized the direct influence of work motivation showed insignificant positive results (inner weight $=0.211, p=0.308$ ) so it can be concluded that the results of the study rejected hypothesis 3 because there is an insignificant influence between work motivation and employee performance. The results showed that $12.3 \%$ of employee performance variables were influenced by workload variables, work experience and work motivation while the remaining $87.7 \%$ were influenced by other variables.
\end{abstract}

Keywords: workload, work experience, work motivation, employee performance 
EFFECT OF WORKLOAD, COMPENSATION AND EMPLOYEE COMMITMENT TO THE EMPLOYEES PERFORMANCE OF PUBLIC WORKS AND SPATIAL ARRANGEMENTS OFFICE OF KARIMUN DISTRICT

DOI: https://doi.org/10.54443/ijset.v1i2.11

\section{INTRODUCTION}

The components of human resources in the organization are no less important than other resources, as expressed by Arifin, Alhabsji, \&Utami (2016) in his research that decisionmaking related to human resources that can impact the performance of employees themselves, because it becomes a necessity for every organization to pay attention to these factors, ranging from placement, promotion to benefits so that human resources in an organization can work optimally in achieving the goals of an organization.

To see the phenomenon of the application of workload, work experience, work motivation and performance assessment for employees; researchers want to review the organization or government agencies, namely in the environment of the Office of Public Works and Spatial Planning Karimun.

Some research on the relationship and influence of work experience and work motivation on employee performance include: Rattu Andrey R. H, Adolfina, Yantje Uhing, (2019) found results that stated that work experience has a significant effect on employee performance. This means that the longer work experience they have, the more knowledge they gain, on the contrary if the less work experience they have, the less knowledge they gain. As for motivation, it has a positive and significant effect on employee performance. The statement can be interpreted that if the work motivation owned by employees is getting bigger, then the employee's performance will be better, otherwise if the work motivation of the employee is small, then the employee's performance is getting worse.

\section{LIBRARY OVERVIEW}

Workload According to Permendagri No. 12 Year 2008 Article 7 paragraph (2) workload is the amount of work that must be carried out by a position / organizational unit and is the result of times between the volume of work and the norm of time. Meanwhile, according to the Minister of Foreign Affairs (1997) workload is a number of work targets or results that must be achieved in one specific unit of time (Kepmenpan No:KEP/75/M.PAN/7/2004, Chapter II A.5).

\section{Workload Indicator}

The workload indicator used adopts from the workload indicator stipulated by Adhani (2013) as follows:

1. The number of jobs given to employees.

2. The level of difficulty of the job given to the employee.

3. The adequacy of time given to the pegaai to complete the work.

4. Knowledge and skills of employees.

\section{Work Experience}

According to Akhmad (2014:53) work experience is one of the determinants in providing one's income in work, where work experience is measured based on the length of time a person performs his/her duties in accordance with the field studied. Employees who have sufficient work experience in their field of work tend to be faster and more accurate in completing the tasks they are responsible for. Work experience for an employee is important. Work experience owned by an employee can be used as the basis by the organization in planning the career development of employees. 


\section{Compensation Indicator}

Compensation indicators as stated by Foster (2001) as follows:

1. Interest in work

2. Skills

3. Knowledge

4. Confidence

\section{Work Motivation}

Work motivation is a psychological process that evokes and directs behavior to the achievement of goals or goal-directed behavior (Kreitner and Kinicki, 2001).

\section{Work Motivation Indicators}

According to Maslow in Robbins (2008) the theory of motivational indicators is as follows:

1. Physiological Needs

2. The Need for Security

3. Social Needs

4. Award Needs

5. The Need for Self-Actualization

\section{Employee Performance}

Performance is the result of quality and quantity achieved by an employee in carrying out his duties in accordance with the responsibilities given to him. Performance is the seriousness of the effort made by a person that impacts the results obtained (Asmani, 2012:130)

\section{Performance Indicators}

According to Mathis and Jackson (2011:378) the performance of public servants for most occupations includes the following elements:

1. Quantity

2. Quality

3. Time-out

4. Attendance

5. Ability to work together

Of the above five elements only three (number one to three) will be used in this study

\section{IMPLEMENTATION METHOD}

This research was conducted in Kuala Sempang Village, Seri Kuala Lobam District, Bintan Regency, where the research was conducted to analyze the effect of Village Asset Management Professionalism, Optimization of Village Asset Utilization and Community Empowerment on Increasing Village Original Income.

The type of data used in this research is quantitative data. Quantitative data is a research method based on the philosophy of positivism, used to examine specific populations or samples, data collection using research instruments, quantitative or statistical data analysis, with the aim of testing predetermined hypotheses (Sugiyono, 2017: 8). In this study, quantitative data is a value or score on the answers given by respondents to the questions in the questionnaire. The data used in 
EFFECT OF WORKLOAD, COMPENSATION AND EMPLOYEE COMMITMENT TO THE EMPLOYEES PERFORMANCE OF PUBLIC WORKS AND SPATIAL ARRANGEMENTS OFFICE OF KARIMUN DISTRICT

DOI: https://doi.org/10.54443/ijset.v1i2.11

this study are primary data, namely research data obtained or collected directly from the original source (without intermediaries). While the data sources in this study were obtained from answers to questionnaires distributed to respondents.

The questionnaire used in this study was measured using a 5-point liker scale using a score range of $1-5$. Respondents were asked to fill in a check mark $(\sqrt{ })$ on the answer that is considered correct on each question item. The scoring used in measuring the questionnaire answers is:

1. Strongly Disagree (STT) with a score interval of 1

2. Disagree (TS) with a score interval of 2

3. Neutral $(\mathrm{N})$ with a score interval of 3

4. Agree (S) with a score interval of 4

5. Strongly Agree with a score interval of 5

The questionnaire consists of four parts, namely: the first variable of professionalism in the management of village assets which consists of 10 question items, the second part is the variable of optimizing village assets utilization which consists of 15 question items, the third part is the variable of community empowerment which consists of 13 question items, and the part that the four variables of village original income consisting of 8 question items.

Population is a generalization area consisting of objects / subjects that have certain qualities and characteristics set by researchers to study and then draw conclusions (Sugiyono, 2017: 80). The population in this study was Kuala Sempang Village, Seri Kuala Lobam District, Bintan Regency which has been calculated using the Slovin formula.

The data analysis method used in this research is validity and reliability test, classical assumption test, hypothesis test. Data analysis was processed using the help of the SPSS Versi20 program

\section{RESULTS AND DISCUSSION}

\section{Types of Research}

The type of research used in this study is associative research whose relationship is influence or not. In this study, associative methods were used to determine the influence of work experience workload and work motivation on employee performance at the Public Works and Spatial Planning Office of Karimun Regency.

\section{Population and Samples}

The sample population is all employees of the Public Works and Spatial Planning Office of Karimun Regency, which is as many as 66 employees.The number of samples to be used is as many as 66 people. The method used is the survey method which is data collection using questionnaires.

\section{Partial Least Square (PLS) Model Scheme}

In this study, hypothesis testing used Partial Least Square (PLS) analysis techniques with smartPLS 3.0 program. The following is the model scheme of the PLS program being tested: 

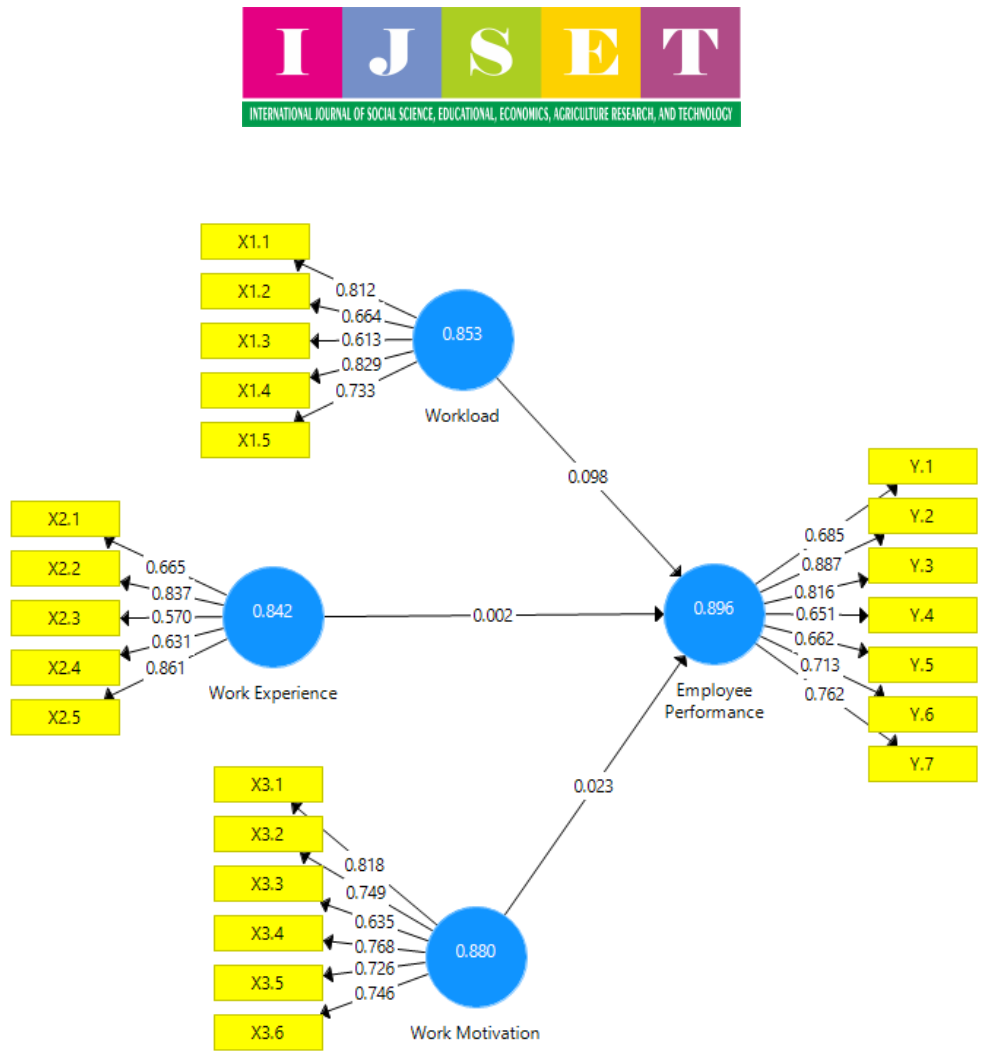

\section{Outer Model Evaluation}

Figure 1. Outer Model

\section{Convergen Validity}

To test convergent validity used outer loading value or loading factor. An indicator is declared to meet the convergent validity in either category if the outer loading value $>0.7$. Here is the outer loading value of each indicator on the research variable:

Based on the data feed in table 2 above, it is known that each indicator of many research variables that have an outer loading value of $>0.7$. However, there are still some indicators that have an outer loading value of $<0.7$. According to Chin as quoted by Imam Ghozali, an outer loading value between $0.5-0.6$ is considered sufficient to qualify for convergent validity. The data above shows that there is no variable indicator whose outer loading value is below 0.5 , so all indicators are declared eligible or valid for research use and can be used for further analysis.

2. Discriminant Validity

This section will describe the results of the discriminant validity test. Test discriminant validity using cross loading value. An indicator is declared to meet the discriminant validity if the cross loading value of the indicator on its variable is the largest compared to other variables. The following are the cross loading values of each indicator:

Based on the data feed in table 3 above can be known that each indicator on the research variable has the largest cross loading value on the variable it formed compared to the cross loading value on other variables. Based on the results obtained, it can be stated that the indicators used in this study have a good discriminant validity in compiling their respective variables.

In addition to observing the cross loading value, discriminant validity can also be known through other methods, namely by looking at the average variant extracted (AVE) value for each indicator required the value must be $>0.5$ for a good model.

\section{Composite Reliability}

Composite Reliability is a part used to test the reliability value of indicators on a variable. A variable can be declared to meet composite reliability if it has a composite reliability value of > 0.6. The following are the composite reliability values of each variable used in this study: 
Based on the data feed in table 5 above, it can be known that the composite reliability value of all research variables $>0.6$. These results indicate that each variable has met composite realibility so it can be concluded that the whole variable has a high level of reliability.

\section{Cronbach Alpha}

The reliability test with composite reability above can be amplified by using the cronbach alpha value. A variable can be declared reliable or meet cronbach alpha if it has a cronbach alpha value $>0.7$. The following is the cronbach alpha value of each variable:

Based on the data feed above in table 6, it can be known that the cronbach alpha value of each research variable $>0.7$. Thus these results may indicate that each research variable has met the requirements of the alpha cronbach value, so it can be concluded that the overall variable has a high level of reliability.

\section{Inner Model Evaluation}

In this study will be explained about the results of coefficient path test, goodness of fit test and hypothesis test.

\section{Path Coefficient Test}

Coefficient path evaluation is used to show how strong the effect or influence of independent variables is to dependent variables. While coefficient determination (R-Square) is used to measure how much endogenous variables are affected by other variables. Chin mentions R2 yields of 0.67 and above for endogenous latent variables in structural models indicating the influence of exogenous variables (which affect) on endogenous (affected) variables falls into either category. Whereas if the result is $0.33-0.67$ then it falls into the moderate category, and if the result is $0.19-0.33$ then it falls into the weak category.

Based on the inner model scheme shown in figure 2, it can be explained that the largest coefficient path value is indicated by the effect of workload on employee performance of 1.444. Then the second largest influence was the influence of work motivation limited employee performance by 1.020 and the least influence shown by the influence of work experience on employee performance of 0.363 .

Based on the breakdown of the results, it shows that the entire variable in this model has a coefficient path with a positive number. This indicates that if the greater the coefficient path value on one independent variable against the dependent variable, the stronger the influence between independent variables on the dependent variable.

Here's the inner model scheme of test results: 

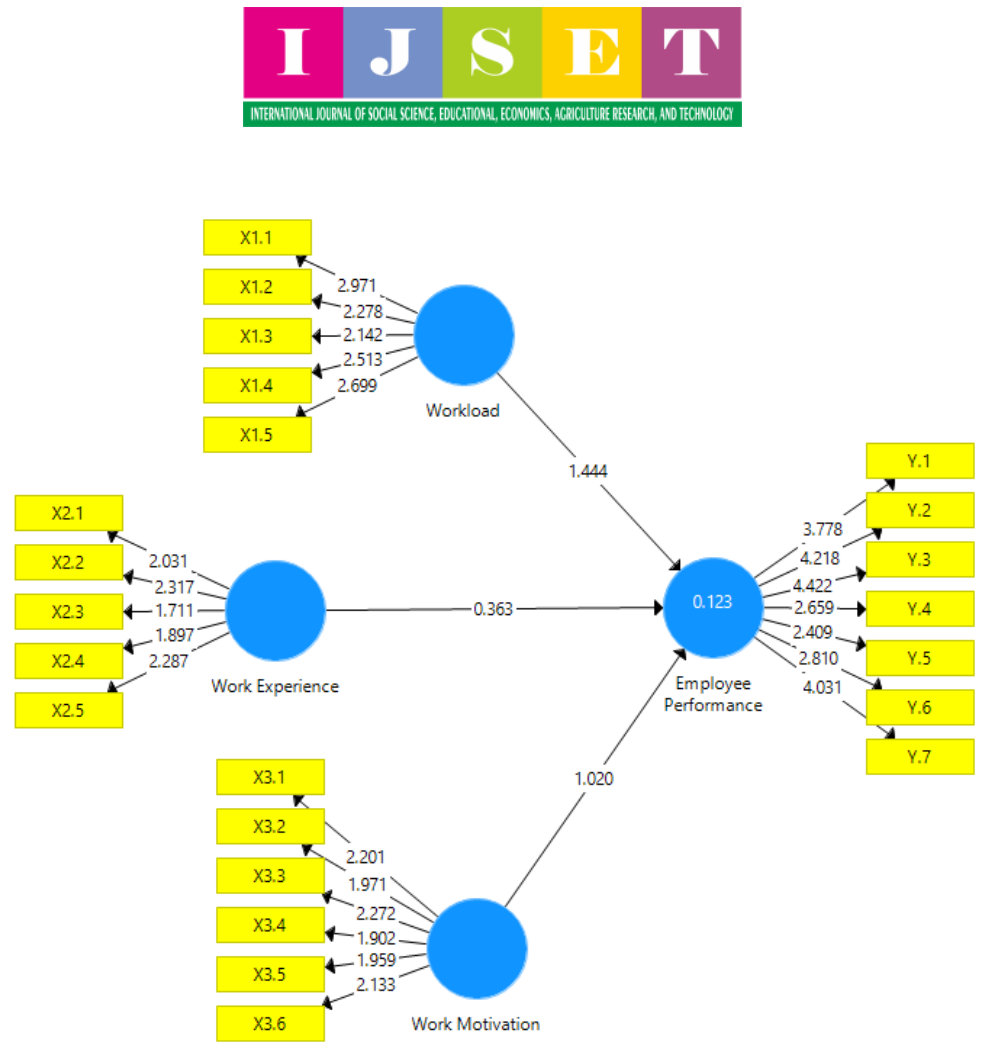

\section{Goodness of Fit Test}

Based on the data processing that has been done using smartPLS 3.0 program, R-Square value is obtained as follows:

Based on the data feed in table 7 above, it can be known that the R-Square value for the employee performance variable is 0.123 . The acquisition of the value explains that the percentage of employee performance can be explained by workload, work experience and work motivation of $12.3 \%$.

The goodness of fit rating is known from the Q-Square value. Q-Square value has the same meaning as coefficient determination (R-Square) in regression analysis, where the higher QSquare, the better or fitter the model can be with the data. The results of the calculation of QSquare value are as follows:

$$
\begin{aligned}
\text { Q-Square } & =1-[(1-\mathrm{R} 2)] \\
& =1-[(1-0,123)] \\
& =1-0,877 \\
& =0,123
\end{aligned}
$$

Based on the calculation result above, the Q-Square value is 0.123 . This shows the amount of diversity from the research data that can be explained by the research model is $12.3 \%$. While the remaining $87.7 \%$ is explained by other factors that are outside the model of this study. Thus, from these results, this research model can be stated to have goodness of fit that is still not good enough.

\section{Hypothesis Test}

Based on the data that has been done, the results can be used to answer hypotheses in this study. The hypothesis test in this study was conducted by looking at T-Statistics values and PValues values. The research hypothesis can be accepted if the P-Values value $<0.05$. The following are the hypothetical test results obtained in this study through the inner model:

Based on the data presented in table 8 above, it can be known that of the three hypotheses proposed in this study, all were rejected because each of the influences shown had a P-Values value of $>0.05$. So that it can be declared an independent variable to its dependencies has an insignificant influence. 
EFFECT OF WORKLOAD, COMPENSATION AND EMPLOYEE COMMITMENT TO THE EMPLOYEES PERFORMANCE OF PUBLIC WORKS AND SPATIAL ARRANGEMENTS OFFICE OF KARIMUN DISTRICT

DOI: https://doi.org/10.54443/ijset.v1i2.11

\section{DISCUSSION}

Based on the overall calculation result, the information can be obtained objectively as follows:

\section{Effect of Workload (X1) on EmployeePerformance (Y)}

The large impact of workload (X1) on employee performance (Y) of -0.302 or $-30.2 \%$, meaning an insignificant increase in workload decreased employee performance by $30.2 \%$. This means that the higher the workload, the performance of employees of the Public Works and Spatial Planning Office of Karimun Regency will decrease. By looking at the results above the Public Works and Spatial Planning Office needs to evaluate the distribution of current workloads so that there is a balance of workloads between employees, then it is necessary to evaluate and analyze the workload thoroughly in order to create optimal workloads, under load and over load each will have impacts such as boredom and stress that can lead to decreased performance.

The results of this study are in line with the results of research conducted nurmalisa, B., et al (2019) which states that the influence of workload on employee performance is a significant negative, if the workload is getting heavier, then the performance of employees will be less good, as well as the results of research conducted by Dharmawan (2011) which states that compensation has a positive and significant effect directly on employee performance, but contrary to the results of research conducted by Adityawarman, et al (2015) stating that workloads have a positive and significant effect directly on the performance of PT employees. Bank Rakyat Indonesia (persero) Tbk Krekot Branch.

\section{Effect of Work Experience (X2) on Employee Performance (Y)}

The magnitude of the influence of work experience (X2) on employee performance (Y) was 0.602 or $6.2 \%$, meaning an increase in work experience insignificantly improved employee performance. This means that the more experience of employees, the higher the performance of employees of the Public Works and Spatial Planning Office of Karimun Regency. The results of this study are in line with research conducted by Riyadi, B. Aries (2015) which states that in theory work experience can affect an employee's performance but it has not been stated correctly before the existence of in-depth research. From this research, it can be known that work experience can not necessarily affect an employee's performance, but there are other factors that can affect an employee's performance as described above.

\section{Effect of Work Motivation (X3) on Employee Performance (Y)}

The magnitude of the influence of work motivation (X3) on employee performance (Y) was 0.212 or $21.2 \%$, meaning that the increase in work motivation did not significantly improve employee performance. This means that the greater the motivation of employees' work, the higher the performance of employees of the Public Works and Spatial Planning Office of Karimun Regency. The results of this study are in line with those expressed by Adha, Risky Nur (2019) suggesting that the results of the third hypothesis test (H3) showed no significant influence between work motivation on employee performance with a signification rate of 0.549 .

The effect of shared workload (X1), work experience (X2) and work motivation (X3) on employee performance $(\mathrm{Y})$ was 0.123 or $12.3 \%$, while the remaining $87.7 \%$ was influenced by other factors not included in this study model. This means that every time there is a change in workload, work experience and work motivation it can affect employee performance up to $12.3 \%$. 


\section{CONCLUSION}

From the results of the data analysis that hasbeen done, several research findings are produced as follows:

1. Workload has a negative and insignificant effect on employee performance, meaning that if the workload gets heavier it will not decrease the performance of employees, on the contrary if the workload faced by employees is lighter then the performance of employees will not be too different when it has more workload. However, it is still expected that the organization to conduct workload analysis in order to be adjusted to the capabilities of employees, so that the productivity produced by employees can be more optimal. Based on this research, it can be concluded that hypothesis 1 that states the workload (X1) has a significant negative effect on the performance of employees (Y) of the Public Works and Spatial Planning Office of Karimun District is rejected.

2. Work experience has a positive and insignificant effect on employee performance, meaning that if the work experience is more and more then the employee's performance will be better. On the other hand, if the work experience of employees is getting less or no work experience at all then the employee's performance will not be too bad. Therefore, agencies are expected to provide more work experience to improve employee performance. Based on this research, it can be concluded that hypothesis 2 which states that work experience (X2) has a significant positive effect on the performance of employees (Y) of the Public Works and Spatial Planning Office of Karimun District is rejected.

3. Work motivation has a positive and insignificant effect on employee performance, meaning that if the employee's work motivation is higher then the employee's performance will also increase, on the contrary if the employee's work motivation is lower then it will not make the employee's performance worse. Based on this research, it can be concluded that hypothesis 3 which states that work motivation (X3) has a significant positive effect on the performance of employees (Y) of the Public Works and Spatial Planning Office of Karimun District is rejected.

4. There is no simultaneous influence between workload variables, work experience and work motivation on the performance variables of employees of the Public Works and Spatial Planning Office of Karimun District as evidenced by the significance value of 0.167 and the coefficient result of 0.123 which means that employee performance can be explained by $12.3 \%$ by workload variables, work experience and work motivation and the rest can be explained by other variables not contained in this study..

\section{REFERENCES}

Adityawarman, Y., Sanim, B., and Sinaga, B.M., (2015), "Effect of Workload on Employee Performance of PT. Bank Rakyat Indonesia (Persero) Tbk Krekot Branch", Journal of Management and Organization", Vol. VI, No. 1, P. 1. 34-44.

Anonimous (2004), KEPMENPAN NUMBER: KEP/75/M.PAN/7/2004 CONCERNING Guidelines for Calculating Employee Needs Based on Workload in the Framework of The Formation of Civil Servants.

Anonimous (2008), Regulation of the Minister of Home Affairs No. 12 of 20018 concerning Guidelines for Workload Analysis within the Ministry of Home Affairs and Local Government.

Fauzi, Latifah Isnaini. (2018) Influence of Work Motivation and Work Experience on Employee Performance (Employee Case Study of PT Adi Satria Abadi), Yogyakarta. 
Ilham, R. N., Erlina, K. A. F., Silalahi, A. S., Saputra, J., \& Albra, W. (2019). Investigation of the bitcoin effects on the country revenues via virtual tax transactions for purchasing management. Int. J Sup. Chain. Mgt Vol, 8(6), 737.

Ilham, R. N., Sinaga, S., Putri, D. E., Sinta, I., \& Fuadi, F. (2021). EFEK DARI LEVERAGE DAN UKURAN PERUSAHAAN DALAM MEMENGARUHI TINGKAT PROFITABILITAS. JURNAL ILMIAH EDUNOMIKA, 5(02).

Khaddafi, M., Subrata, H., Apriyanto, E., Iqbal, M., \& Darmawan, W. (2022). PENGENALAN DASAR PENGOPERASIAN KOMPUTER PADA ANAK USIA DINI. JATIMIKA: Jurnal Kreativitas Mahasiswa Informatika, 2(3).

Mathis, L.R. and J.H. Jackson. (2006) Human Resource Management. Jakarta, Salemba Empat.

Riinawati, R. (2021). The Development of Information Technology and Its Influence on the Field of Management Accounting. Journal of Financial and Tax, 1(2), 131-149.

Sari, Mei Rachma. (2019), Effect of Compensation, Workload and Work Environment on Employee Performance of PT Traktor Nusantara Surabaya Branch, Surabaya. 